63: 71-116, 1895 .

5) Arnold, J.: Myelocyste, Transposition von Gewebskeimen und Sympodie. Beitr. z. pathol. Anat. u.z. allg. Patol., 16: 1-28, 1894.

\title{
Discussion to Dr. Pudenz' Speech (2)
}

\author{
Komei UEKI \\ Dept. of Neurosurgery, Brain Research Institute, Niigata Univ. School of Medicine
}

We have been most fortunate to have an occasion to hear Dr. Pudenz discusses his work. His results are clear-cut and his analysis of the clinical data is excellent. I think all can agree, that for the present time at least, his procedure is the one of choice from the many procedures availabe for the treatment of congenital hydrocephalus.

We too have had experience in his method with good results even though the instruments used by us are modified in some respects to his instruments. For example, in our series there were two slits in the cardiac tube and no diaphragm valve for the flushing device. It will be noted that in tables 1 and 2, the clinical results obtained with this method are obviously better than those obtained by previously used methods. In respect to the newer method however, it must unfortunately be pointed out, that in some instances we experienced an obstruction to the cardiac end of the tube. Out of twenty four cases, five had to be subjected to repeated operation two or three times.

On the other hand, in previous series, a thrombosis of the major arteries or veins was a common occurence; in the newer method such a complication was not encountered in our experience. I wonder if this finding, together with the experience of other workers in the field of general surgery, does not indicate that thrombosis occures less frequently in the Japanese. In

Table 1. Results of ventriculoatriostomy (1.5 Months to 3 Years)

\begin{tabular}{lr}
\hline 1) Alive: \\
Hydrocephalus arrested & 16 \\
& Still progressive \\
2) Dead & 2 \\
3) Unknown & 5 \\
\hline Total & 1 \\
\hline
\end{tabular}

Table 2. Surgical results of hydrocephalus under two years of age

\begin{tabular}{|c|c|c|c|c|c|}
\hline & Alive & $\begin{array}{l}\text { Dead } \\
\text { within } \\
\text { one } \\
\text { month }\end{array}$ & $\begin{array}{c}\text { Dead } \\
\text { over } \\
\text { one } \\
\text { month }\end{array}$ & $\begin{array}{c}\text { Un- } \\
\text { known }\end{array}$ & Total \\
\hline V. mastoidost. & & 2 & 2 & & 3 \\
\hline Torkildsen's proc. & & 1 & & & 1 \\
\hline V. peritoneost. & & 1 & & & 1 \\
\hline V. salpingost. & & & & 1 & 1 \\
\hline Plexect. & & 1 & & & 1 \\
\hline V. atriost. & 11 & 3 & 2 & 1 & 17 \\
\hline Total & & & & & 24 \\
\hline
\end{tabular}


two cases in our series we observed evidence of an inflamatory process.

In the group of cases with obstructive hydrocephalus, the local procedure alone was often unsuccessful in the treatment of some groups, i. e. nonneoplastic stenosis of the aqueduct of Sylvius, the Dandy-Walker syndrome, the Arnold Chiari malformation. The reason for this, I believe, is the fact that these groups originally belonged to the congenital malformation groups and they should be studied as diseases of the entire central nervous system rather than localised pathological processes. It seems therefore, from a viewpont of treatment, that the clear-cut distinction between obstructive hydrocephalus and communicating hydrocephalus becomes less important. Thank you. 